\title{
Study on the Ideological and Political Education in Higher Vocational Colleges in New Media Era
}

\author{
Xiao Huimin \\ Shandong Labor Vocational and Technical College, Ji'nan City, Shandong province 250022
}

Keywords: new media; higher vocational colleges; ideological and political education research

\begin{abstract}
The principal of ideological and political education of students in higher vocational colleges should realize the advent of the era of new media, bring the good development of higher vocational ideological and political education in all areas at the same time. While it also faces various problems. This paper proposes the application of the new media for higher vocational ideological and political education in classroom teaching, resource selection, student awareness, educators and other aspects, gives corresponding methods and strategies. Efforts should be made to promote the ideological and political education in higher vocational colleges under the new media environment, to enhance students' ideological awareness and moral practice, and to promote the idea of ideological and political education into the soul of students.
\end{abstract}

\section{Introduction}

From China in recent years, the change can be seen, the development of science and technology is very fast. Before a lot of people will get information through the media, newspapers and television, but now more and more new media appear in front of the public, the use of mobile phone computer to mobile devices such as the dissemination of information, bring great convenience to people's lives. We believe that, based on information technology, the use of new media platforms, such as WeChat, QQ, micro-blog and so on, to spread information for our purpose, we have become the new media. Because of its fast and convenient, has been widely used in various fields of life. Education is no exception, so the application of new media in the ideological and political education is inevitable.

\section{A new media era for Higher Vocational Ideological and political education opportunities}

In the past education background, teachers and students in higher vocational colleges can only learn ideological and political education through textbooks, newspapers, radio and other ways. The update speed of information is slow and resources are often relatively simple. With the application of new media in higher vocational colleges, various platforms provide a wealth of learning resources for teachers and students, so that teachers and students can quickly obtain information resources. In addition, the new media uses pictures, pictures, animation, video and other means of communication, so that the ideological and political content more vivid image, greatly attracted the attention of students, so that students have a strong interest in learning [1].

Before the new media in Higher Vocational Ideological and political courses, students' academic achievements and teachers' teaching level have a lot to do with, because the students at that time mainly through textbooks and teachers to explain to receive knowledge. Then, the application of new media in the ideological and political education, access to resources becomes more and more abundant, to reduce their dependence on teachers, students tend to make autonomous learning, enhance students desire for knowledge. In addition, the people of non real-time remote communication of new media, such as anonymous QQ communication between the two sides, idea of students to teachers or administrators boldly and freely exchange their thoughts, produce more collision [2].

The educational background of the generation and development of the new media, the development of the traditional education mode is not suitable for students, but also can not meet the 
students' pursuit of advanced ideological and political philosophy, which has brought profound influence to the ideological and political education. In the curriculum, campus network, WeChat public number, campus ideological and political forum to students like to appear in the daily life, so that students take the initiative to build on their knowledge structure, also increases the interactive communication between teachers and students. In this way, the combination of new media and traditional education enriches the form of education, makes students have a strong interest in the ideological and political course, and promote the construction of knowledge [3].

\section{The new media era for Higher Vocational Ideological and political education challenge}

In the new media environment, not only the education resource types, and a variety of entertainment information emerge in an endless stream. In higher vocational colleges, there are a lot of students self-control ability is relatively weak, in the classroom with a mobile phone or iPad and other small new media, especially the ideological and political course that can listen or not listen, it brings some negative effects to the classroom teaching. In addition, convenient access to educational resources and efficient use of new media, a lot of work to help the students to use learning software to cope with work or classroom questioning, and not to think for themselves, which have a negative impact on the construction of students' knowledge.

With the combination of traditional education and new media, teachers often encourage students to study independently by rich media resources, access to resources in the fast and convenient at the same time, students often cannot obtain the effective resources for learning. Because there are a lot of information, the Internet platform is uncertain and not true, and the students' discrimination ability is very limited, can not get useful information from complex information, will be in the ocean of information lost in their own direction, diversity of resources to a certain extent will reduce the effect of the ideological and political teaching.

The educational environment in the new media era is conducive to the construction of students' Ideological and political cognition, but there are also great hidden dangers. Under the new media era of information, a variety of the dragons and fishes jumbled together, causing difficulties in supervision information. Some virtual, vulgar, anti ideological information easily influence the students, usually higher vocational college students lack of social experience, has not formed the correct values, negative information once indulged in the attraction of large, it is easy for students to construct the wrong cognition content, go on the road of Ideological and political right deviation.

Under the new media era, the update speed of information quickly, need educators to grasp the method of using media. If a teacher is not perfect information technology support, so can not enjoy the convenience of new media. This is not conducive to promoting the development of education informatization, to improve teaching efficiency and keeping pace with the times. In addition, teachers must have a high ideological and political literacy, otherwise it is vulnerable to the network of miscellaneous information impact, thereby affecting the students' learning content. Therefore, teachers should be able to accurately and effectively judge the information, give full play to the scientific knowledge of Ideological and political education, improve their overall quality, and do a good job of Ideological and political education [4].

\section{The new mode of Ideological and political education, three under the age of new media}

In higher vocational colleges, the overall quality of students is uneven, most of the students have their own personality, coupled with the lack of social experience, in the ideological aspects is not very mature. In addition, the overall cultural level of the students is lower than that of other schools focusing on academic research. In the traditional ideological and political education, teachers combine textbooks to teach students knowledge in a single way to instill systematic ideological culture. However, in view of the characteristics of higher vocational students, the traditional ideological and political education model can not meet the pursuit of advanced political ideas, nor attract the attention of students, stimulate their interest in learning. Therefore, we need to change the traditional education idea, to combine the effective mode of rapid development of new media and 
the traditional education in the appropriate combination, promote teaching and students to construct knowledge actively, make the ideological and political classroom radiate vivid and diverse forms.

When the ideological and political education in higher vocational colleges is combined with the new media, on the one hand, the media should be combined with the characteristics of the subject itself so as to highlight the key or difficult points of teaching. On the other hand, with the development of information technology, the new media not only appears in education, but also permeates every field of life. We have great benefits, cannot do without the new media brings to life the theoretical knowledge of Higher Vocational Ideological and political the student should run through the whole social life, social thought through creating a good environment, to cultivate innovative talents with high level of thought [5].

Under the new media era, the network resources are diverse, it is easy to lose themselves in the ocean of information. Therefore, higher vocational colleges of Ideological and political education workers should not only remind students, and will also be in the choice of educational content, through socialist ideological line, "do everything from reality, theory and practice, seeking truth from facts" philosophy of education, to be close to students' life, people-oriented, learning theory and practice of students it really can choose effective knowledge to promote students' Ideological and political education. To ensure the ideological and political education can be carried out.

When choosing the content of Ideological and political education, we should not only conform to the socialist ideological line, but also close to the students' life, and integrate some theoretical knowledge into the social life or practice of students. Practical education should pay attention to the content, if it is free to find some media resources in a long and minute statement, the consequences are likely to be too abstract for students' ideological theory cannot understand or students can understand the idea of truth is too simple. We should pay attention to train the content of education on students' knowledge and learning ability, higher vocational students compared with theoretical knowledge in terms of pay more attention to the role of practice, so students should strive to learn scientific knowledge system, and put the knowledge into practical skills, social practice for the future work to pave the way for. Finally, the students' physical and mental quality, ideological and moral education to the life of people, when using new media resources, to enhance their ability to identify effective resource selection positive, the work of Ideological and political education.

In higher vocational colleges, there is a difference between students, and the traditional ideological and political education is a class of dozens of students in the classroom lectures, students of different styles are very different for receiving the unity of knowledge; in class, a few students to teachers of Ideological and political communication problems, teachers and a lot of research and practice work, students and teachers can contact less and less, so the teachers should go deep understanding of each student and cognitive characteristics for students for education is very difficult and complex task. But the arrival of the new media era, a lot for a variety of learning resources in the form of increased network platform, according to the screening of educational content, the ideological and political issues of politics, around the text, pictures, sound, video, animation and other forms in front of the students, the education forms, students can choose their own way of learning to complete their courses within the specified time according to the basic level, grasp the knowledge points. In order to enhance the effectiveness and pertinence of the classroom.

In recent years, the employment problems of students caused social concern about. The future employment of students is closely related to the study in school, not to say that reading the university is equal to solving the future life orientation. Modern market employment competition is very fierce, not only higher vocational colleges, schools all over the country have expanded enrollment, college students increased year by year. In the face of this form, higher vocational school education should take into account the future employment of students, so that learning knowledge into the social practice, pay attention to the practicality and development of teaching [6].

In the traditional ideological and political education, as long as teachers need to master the scientific and systematic ideological and political theory knowledge, they can be instilled into the students in the classroom. But in the era of new media, which is not suitable for the new education model. Educators engaged in Ideological and political education must master new media, such as 
computers, mobile phones, information technology and so on. This is the basis for teachers to timely make the students learn the latest thinking results. With the help of these media, teachers and students can communicate at any time to improve students' awareness of the ideological and political. But at the same time, educators also have the responsibility to monitor students' correct use of new media, and protect students from the impact of the network of miscellaneous information.

In the new media environment, the role of teachers can not be replaced, he changed from the traditional leader to organizers, collaborators and guides, with multiple identities and more onerous task appeared in education and teaching. Therefore, the ideological and political education of higher vocational educators need to adjust their mode of operation, strengthen the organization of training, the stringent requirements of the various aspects of teachers, improve the comprehensive quality of education and improve the construction of Ideological and political education work team in Higher Vocational colleges. Four, concluding remarks

Although the new media for Higher Vocational Ideological and political education is a doubleedged sword, that is, there are many opportunities for development, but also facing a series of challenges. But we can not because of fear of adverse effects and give up the opportunity. We should believe that as long as the higher vocational colleges make the best use of the situation, give full play to the favorable role and occupy the ideological and political main position, it can help the students develop in a healthy way.

\section{References}

[1] Shen Jing. Analysis of Ideological and political education in Higher Vocational Colleges under the new media environment [J]. modern vocational education, 2016, (36): 68.

[2] Yang Zijian. Innovation and development of Ideological and political education in Higher Vocational Education under new media environment [J]. teaching in forest region, 2016, (11): 6263.

[3] Wang X. Discussion on Ideological and Political Education of Higher Vocational College Students under the New Media Environment_—Based on the Questionnaire of 5 Vocational Colleges in Xiamen [J]. Journal of Huanggang Polytechnic, 2016.

[4] Bai N. Exploration of Ideological and Political Education in Higher Vocational Colleges Under the Background of New Media [J]. Shipbuilding Vocational Education, 2016.

[5] Hu X. On the Innovation of Ideological and Political Education in Higher Vocational Colleges in the New Media Era [J]. Science Education Article Collects, 2017.

[6] Chen H, Lin-Zhi H E, De-Zhi A N. Analysis of Multi-dimensional Path of Ideological and Political Education Carrier in Higher Vocational Colleges in New Media Era [J]. Journal of Hubei Correspondence University, 2014

[7] Xiao Huimin (1979.7-), female, Han nationality, Shandong Jinan, lecturer, master, mainly engaged in the research of Ideological and Political Education 